\title{
Evaluation of Low Cost Drip Irrigation Technology Through Tomato Production: In Adami Tulu JidoKombolcha District, Mid-Rift Valley of Ethiopia
}

\author{
Abay Challa*, Zelalem Shelemew, Anbase Ambonsa \\ Adami Tulu Agricultural Research Center, Zeway, Ethiopia \\ Email address: \\ abaychalla@gmail.com (A. Challa) \\ ${ }^{*}$ Corresponding author

\section{To cite this article:} \\ Abay Challa, Zelalem Shelemew, Anbase Ambonsa. Evaluation of Low Cost Drip Irrigation Technology Through Tomato Production: In \\ Adami Tulu JidoKombolcha District, Mid-Rift Valley of Ethiopia. International Journal of Natural Resource Ecology and Management. \\ Vol. 2, No. 2, 2017, pp. 32-37. doi: 10.11648/j.ijnrem.20170202.13
}

Received: September 29, 2016; Accepted: February 3, 2017; Published: March 15, 2017

\begin{abstract}
Evaluation of low cost drip irrigation technology was carried out under soil and agro climatic condition of Adami Tulu Agricultural Research Center, on-station so as to see its performance as compared to furrow irrigation systems for increased tomato productions. Four improved tomato verities were used for the purpose as test crop. The trials were replicated four times in a randomized block design. Some parameters of tomato and water use efficiency were used to compare the performance of the two irrigation systems. There was observed difference in some parameters of tomato under the two irrigation systems. Some tomato varieties perform well under drip while other performs well under furrow. But, the overall effect showed that drip irrigation system performed better than furrow irrigation system. Relatively higher mean yield of tomato was recorded under drip irrigation systems; 44.09 ton/ha for drip as compared to 43.38 ton/ha in surface irrigation. Drip irrigation used less water than that of surface irrigation systems, thus, giving much higher water use efficiencies. It was concluded that low cost drip systems achieved water saving of more than 25.9 as compared to surface irrigation systems. Finally this technology needs further evaluation under farmer circumstance for better finding.
\end{abstract}

Keywords: Surface Irrigation, Low Cost Drip Irrigation, Tomato and Water Use Efficiencies

\section{Introduction}

Huge proportion of the population (more than $85 \%$ ) in Ethiopia is engaged in less productive agricultural activities. This low productive rain-fed small-holder agriculture is the main source of food supply in the country. With this regard, unreliable distribution of rainfall represents critical constraint to enough food production and is the major cause for food self insufficiency and famine in the country. Under these conditions, implementation of irrigation is considered necessary to sustain food production. Irrigation implies the application of suitable water to crops in right amount at the right time. Irrigation reduces the risk of expensive inputs being wasted by crop failure resulting from moisture stress [8]. Therefore, an effort to improving water productivity, careful application to promote growth and yield and enhance the economic efficiency of crop production is vital. The selection of the appropriate irrigation method can increase water use efficiency and reduce the demand on fresh water [9].

Reports showed that, low cost drip irrigation (LCDI) is in use in over 80 countries worldwide and the demand is growing fast. In Africa, it is being used in Kenya, Tanzania, Malawi, Zambia and Uganda [10]. Elsewhere in the world, for example in India, resource-poor farmers have used LCDI systems with reported success [10]. Micro irrigation systems have been found to be superior in terms of water and nutrient saving and higher productivity of many crops [6]. Micro irrigation system was found to result in 30 to $70 \%$ water savings in various orchard crops and vegetables along with 10 to $60 \%$ increases in yield as compared to conventional methods of irrigation [2]. It is wise to make efficient use of water and bring more area under irrigation through limited water resources. This can be achieved by introducing advanced methods of irrigation and improved water management practices [21].

Drip irrigation has superiority over traditional irrigation 
methods in terms of yield and economics [14]. Conventional drip irrigation systems typically cost US\$ 5,000 -10,000 ha-1, or much more, installed in East Africa [10]. Experiences from Arba Minch University shows that a single low-cost drip irrigation system of $60-70$ birr initial cost can supply family with fresh vegetable for home consumption from $7.5 \mathrm{~m}^{2}$ area of land [7]. Reports from other country shows, coupling of LCDI technologies with water harvesting technologies allows better control and management of limited water resources and results in much higher returns to farmers.

Small-scale, LCDI systems that can be easily afforded and managed by poor farmers contribute significantly to the endeavors of ensuring food self-sufficiency at household level. Thus alternative methods such as low-cost smallholder irrigation technologies are vital and attractive. The present study was, therefore, conducted to evaluate low cost drip irrigation technology through tomato production under the agro climatic condition of the study area.

\section{Material and Methods}

\subsection{Description of the Study Area}

The experiment was conducted at the experimental site of Adami Tulu Agricultural Research Centre. It lies at $7^{\circ} 9^{\prime}$ Nlatitude and $38^{\circ} 7^{\prime}$ 'E longitude; and altitude of about 1650 meters above sea level. The rainfall is bimodal and unevenly distributed with average annual rainfall of $760 \mathrm{~mm}$. The minor and main rainfall periods are from February to April and July to September, respectively. The soil is loam with sand, silt and clay in proportion of $44 \%, 34 \%$ and $22 \%$ respectively and $\mathrm{pH}$ of the soil is 7.88 [20].

\subsection{Materials Used}

The material used for the experiment was bucket with the temporary water storage (water source) near to the plot to fill the bucket. The water is lifted manually by labor to fill the bucket. Woods for pillars of bucket at 0.8 heights from the point where the blind hose was situated to maintain the $92.4 \%$ distribution uniformity were used. The blind hose (16 and $4.5 \mathrm{~mm}$ diameter) with $0.8-1 \mathrm{~mm}$ diameter micro tube, plastic bottles, mesh filter (locally known as 'shash') were also used. Partial flume was used for furrow irrigation system water measurement. Tomato which is most economical crops in the area was used for the experiments.

\subsection{Experimental Methodology}

The study was conducted at Adami Tulu Agricultural Research Center on station during off season (2013/14 cropping season). The experiment had two factors; namely two irrigation type (micro tube and furrow irrigation and four tomato varieties (Chali, Melkashola, Fetan and Cochoro) that were combined factorial giving a total of eight treatments. The treatment was installed on well prepared fields of 0.036ha areas to grow the tomato crops. The seeds of selected nationally released tomato varieties were sowed on nursery bed. The seedlings were then transplanted on well prepared experimental plots. The recommended fertilizer rate of $200 \mathrm{~kg} \mathrm{ha}^{-1}$ DAP and $100 \mathrm{~kg} \mathrm{ha}^{-1}$ Urea were applied at time of sowing and two weeks after transplanting [5]. Other agronomic and crop protection practices (weeding, watering and pesticides) were adopted uniformly as per recommendation for tomato production.

Depending on the recommended plant spacing a single laterals line was used for a single row of tomato varieties. The spacing between lateral lines and emitters is $1 \mathrm{~m}$ and $0.5 \mathrm{~m}$ respectively. In one bucket there were four mesh covered plastic bottle (filter) that attached with $4.5 \mathrm{~mm}$ diameter blind hose in order to convey pure water into four laterals (Figure 1).

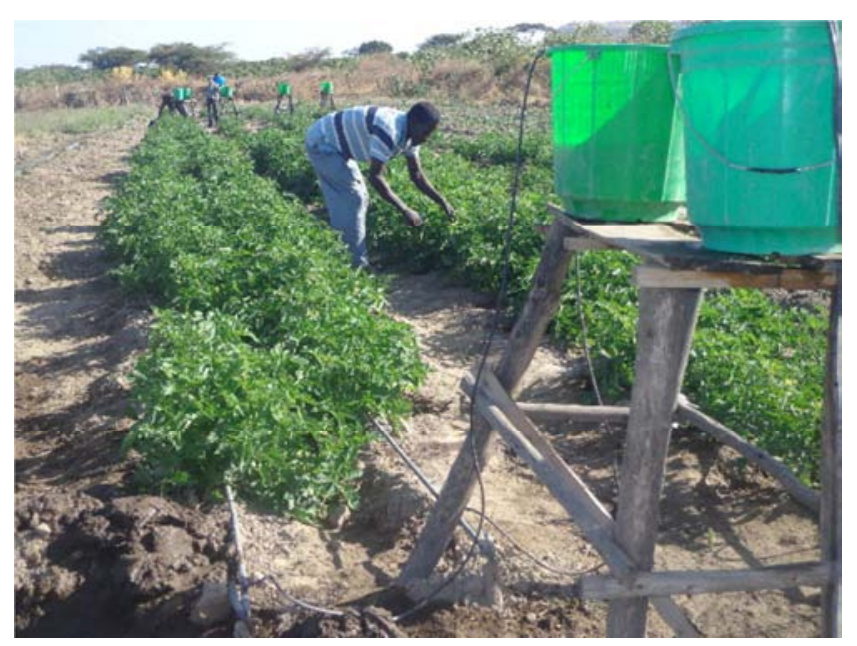

Figure 1. Low costbucket drip irrigation system mounted $0.8 \mathrm{~m}$ above the ground on a stand constructed from wood. (Picture taken was on January 2014).

Water is delivered to the crops through micro tubes /emitters in blind hose of $16 \mathrm{~mm}$ diameter. Crops are planted next to the holes, so that the soil around the plant is kept wet without wasting any water. Irrigation with low cost drip system should be applied in shorter duration (daily or every other day) to maintain high level of soil moisture and meet the crop water requirement which is lost between irrigation hence the interval of bucket filling depend on crop water requirement.

Water Productivity (WP)

Water productivity was determined by dividing beneficial fruit yield by total applied irrigation water and is expressed as follows [1].

$\mathrm{WP}=\mathrm{BY} / \mathrm{Wa}$ where BY is beneficial yield $\left(\mathrm{kg} \mathrm{ha}^{-1}\right)$ and $\mathrm{Wa}$ is total irrigation applied water $\left(\mathrm{m}^{3} \mathrm{ha}^{-1}\right)$.

\subsection{Data Analysis}

Irrigation method and tomato variety were used as independent variables and parameters of tomato as dependent variables. The effects of irrigation system and variety on parameters of tomato were tested by two way analysis of variances. The parameters of tomato were subjected to analysis of variance using the general liner model procedure of the statistical analysis system (SAS, version 9.0). 
Whenever significant difference $(\mathrm{p}<0.05)$ due to irrigation system and variety for assessed parameter is observed, a mean separation for each parameter was made using least significant difference (LSD).

\section{Result and Discussions}

Results of the analysis of variance (ANOVA) showed significant difference for most of the characters between the irrigation systems.

Table 1. Tomato yield and other yield related parameters under drip irrigation method.

\begin{tabular}{llll}
\hline Varity of tomato & Fruit weight $(\mathbf{g})$ & Fruit width(cm) & Fruit length (cm) \\
\hline Chali & $81.25 \mathrm{~b}$ & $5.24 \mathrm{a}$ & $5.26 \mathrm{a}$ \\
Melka shola & $61.35 \mathrm{c}$ & $4.48 \mathrm{a}$ & $5.77 \mathrm{a}$ \\
Fetan & $100.75 \mathrm{a}$ & $4.90 \mathrm{a}$ & $5.05 \mathrm{a}$ \\
Cochoro & $67.75 \mathrm{c}$ & $5.2 \mathrm{a}$ & $5.27 \mathrm{a}$ \\
Mean & 77.77 & 4.96 & 5.34 \\
LSD0.05 & 8.67 & Ns & Ns \\
CV\% & 6.97 & 11.72 & 13.02 \\
\hline
\end{tabular}

Means followed by the same latter (a) or (b) vertically for each variable are not significantly different at $(p \leq 0.05)$ with respect to irrigation system. $C V=$ coefficient of variation

Table 2. Tomato growth parameters under drip irrigation method.

\begin{tabular}{lllll}
\hline Varity of tomato & Plantheight $(\mathbf{c m})$ & No of Branch/plant & No fruit per plant & No of cluster per plant \\
\hline Chali & $51.90 \mathrm{ab}$ & $7.45 \mathrm{a}$ & $31.15 \mathrm{a}$ & $8.15 \mathrm{a}$ \\
Melka shola & $58.2 \mathrm{a}$ & $5.80 \mathrm{~b}$ & $35.03 \mathrm{a}$ & $8.37 \mathrm{a}$ \\
Fetan & $46.30 \mathrm{~b}$ & $8.12 \mathrm{a}$ & $18.22 \mathrm{~b}$ & $6.12 \mathrm{~b}$ \\
Cochoro & $52.45 \mathrm{ab}$ & $5.02 \mathrm{c}$ & $35.57 \mathrm{a}$ & $8.61 \mathrm{a}$ \\
Mean & 52.21 & 6.59 & 29.99 & 7.81 \\
LSD0.05 & 10.02 & 0.67 & 1.48 & 1.46 \\
CV\% & 11.99 & 6.39 & 3.09 & 11.67 \\
\hline
\end{tabular}

Means followed by the same latter (a) or (b) vertically for each variable are not significantly different at $(p \leqslant 0.05)$ with respect to irrigation system. $C V=$ coefficient of variation

Table 3. Tomato yield and other yield related parameters under furrow irrigation method.

\begin{tabular}{|c|c|c|c|c|}
\hline Varity of tomato & Fruit weight (g) & Fruit width(cm) & Fruit length (cm) & yield (tonha $\left.{ }^{-1}\right)$ \\
\hline Chali & $76.5 b$ & $4.51 \mathrm{a}$ & $5.35 \mathrm{a}$ & $42.77 \mathrm{c}$ \\
\hline Melka shola & $60.00 \mathrm{~d}$ & $4.25 \mathrm{a}$ & $5.35 \mathrm{a}$ & $42.30 c$ \\
\hline Fetan & $88.50 \mathrm{a}$ & $4.64 \mathrm{a}$ & $5.27 \mathrm{a}$ & $43.70 \mathrm{~b}$ \\
\hline Cochoro & $66.25 \mathrm{c}$ & $4.10 \mathrm{a}$ & $5.00 \mathrm{a}$ & $44.75 \mathrm{a}$ \\
\hline Mean & 72.81 & 4.37 & 5.24 & 43.38 \\
\hline LSD0.05 & 2.97 & Ns & Ns & 6.37 \\
\hline $\mathrm{CV} \%$ & 2.55 & 13.37 & 10.87 & 0.92 \\
\hline
\end{tabular}

Means followed by the same latter (a) or (b) vertically for each variable are not significantly different at $(p \leq 0.05)$ with respect to irrigation system. $C V=$ coefficient of variation

Table 4. Tomato growth parameters under furrow irrigation.

\begin{tabular}{|c|c|c|c|c|}
\hline Varity of tomato & Plant height(cm) & No of branch/plant & No of fruit per plant & cluster \\
\hline Chali & $75.06 \mathrm{~b}$ & $7.00 \mathrm{a}$ & $32.25 \mathrm{a}$ & $7.50 \mathrm{c}$ \\
\hline Melka shola & $95.12 \mathrm{a}$ & $6.02 \mathrm{a}$ & $33.03 \mathrm{a}$ & $11.04 \mathrm{~b}$ \\
\hline Fetan & $59.37 \mathrm{c}$ & $7.87 \mathrm{a}$ & $21.01 \mathrm{a}$ & $5.91 d$ \\
\hline Cochoro & $72.31 \mathrm{~b}$ & $6.25 \mathrm{a}$ & $34.50 \mathrm{a}$ & $15.05 \mathrm{a}$ \\
\hline Mean & 75.47 & 6.78 & 30.19 & 9.87 \\
\hline LSD0.05 & 6.78 & 1.04 & 4.83 & 0.69 \\
\hline $\mathrm{CV} \%$ & 5.62 & 9.57 & 10.00 & 4.39 \\
\hline
\end{tabular}

Means followed by the same latter (a) or (b) vertically for each variable are not significantly different at ( $p \leq 0.05)$ with respect to irrigation system.

Table 5. Comparison of tomato yield and other yield relatedparameters undertwo irrigationsystems.

\begin{tabular}{|c|c|c|c|c|}
\hline Irrigation system & Fruit weight (g) & Fruit width(cm) & Fruit length $(\mathrm{cm})$ & yield (tonha ${ }^{-1}$ ) \\
\hline Drip & $77.77 \mathrm{a}$ & $4.96 \mathrm{a}$ & $5.34 \mathrm{a}$ & $44.09 \mathrm{a}$ \\
\hline furrow & $72.81 \mathrm{~b}$ & $4.37 \mathrm{~b}$ & $5.24 \mathrm{a}$ & $43.38 \mathrm{a}$ \\
\hline Mean & 75.29 & 4.67 & 5.28 & 43.73 \\
\hline LSD0.05 & 3.23 & 0.42 & NS & 2.86 \\
\hline $\mathrm{CV} \%$ & 5.88 & 12.36 & 11.37 & 0.89 \\
\hline
\end{tabular}

Means followed by the same latter (a) or (b) vertically for each variable are not significantly different at $(p \leq 0.05)$ with respect to irrigation system. $C V=$ coefficient of variation 
Table 6. Comparison of tomato growth parameters undertwo irrigation systems.

\begin{tabular}{lllll}
\hline Irrigation system & Plantheight $(\mathbf{c m})$ & No fruit/plant & No of branch/plant \\
\hline Drip & $52.21 \mathrm{~b}$ & $29.99 \mathrm{a}$ & $6.59 \mathrm{a}$ & No. cluster/plant \\
Furrow & $75.47 \mathrm{a}$ & $30.19 \mathrm{a}$ & $6.78 \mathrm{a}$ & $7.81 \mathrm{~b}$ \\
mean & 63.84 & 30.09 & 6.69 & $9.87 \mathrm{a}$ \\
LSD0.05 & 4.98 & Ns & NS & 8.84 \\
CV\% & 10.70 & 7.97 & 9.49 & 1.36 \\
\hline
\end{tabular}

Means followed by the same latter (a) or (b) vertically for each variable are not significantly different at $(\mathrm{p} \leq 0.05)$ with respect to irrigation system. $\mathrm{CV}=$ coefficient of variation

Table 7. Pearson correlation coefficient of fruit yield (ton $\mathrm{ha}^{-1}$ ) with other characters of tomato variety.

\begin{tabular}{|c|c|c|c|c|c|c|c|c|}
\hline parameters & $\begin{array}{l}\text { Fruit } \\
\text { weight }\end{array}$ & $\begin{array}{l}\text { Fruit } \\
\text { length }\end{array}$ & $\begin{array}{l}\text { fruit } \\
\text { Width }\end{array}$ & $\begin{array}{l}\text { plant } \\
\text { height }\end{array}$ & $\begin{array}{l}\text { No branch per } \\
\text { plant }\end{array}$ & $\begin{array}{l}\text { No Fruit per } \\
\text { plant }\end{array}$ & $\begin{array}{l}\text { NoCluster per } \\
\text { plant }\end{array}$ & Yield ton $\mathrm{ha}^{-1}$ \\
\hline Fruit weight & 1 & -0.08 & 0.30 & $-0.54 *$ & 0.76 & $-0.81 *$ & $-0.54 *$ & 0.31 \\
\hline Fruit length & & 1 & 0.07 & 0.10 & -0.13 & 0.08 & -0.08 & -0.29 \\
\hline Plantheight & & & & 1 & -0.27 & 0.35 & $0.49 *$ & $-0.59 *$ \\
\hline No branch per plant & & & & & 1 & $-0.70^{*}$ & -0.32 & $0 . .01$ \\
\hline No fruit per plant & & & & & & 1 & $0.57 *$ & 0.21 \\
\hline Yield(ton ha $\left.^{-1}\right)$ & & & & & & & & 1 \\
\hline
\end{tabular}

* Significant at the 0.05 level

Table 8. Yield obtained and total irrigation water used $\left(\mathrm{m}^{3}\right)$ for lha of land under two irrigation methods.

\begin{tabular}{|c|c|c|c|c|c|c|c|c|}
\hline \multirow[t]{2}{*}{ crop } & \multicolumn{3}{|c|}{ Yield in ton $\mathrm{ha}^{-1}$} & \multirow[t]{2}{*}{ Unit costkg ${ }^{-1}$} & \multirow{2}{*}{$\begin{array}{l}\text { Estimated cost in birr for } \\
\text { drip } \\
\text { Total cost in birr(100cents) }\end{array}$} & \multirow{2}{*}{$\begin{array}{l}\text { Estimated cost in birr for } \\
\text { furrow } \\
\text { Total cost in birr(100cents) } \\
\end{array}$} & \multicolumn{2}{|c|}{ Water Supplied $\left(\mathbf{m}^{3}\right)$} \\
\hline & furrow & drip & Increase in $\%$ & & & & furrow drip & Water saving in \% \\
\hline tomato & 43.38 & 44.09 & 1.6 & 10 & 440900 & 43380 & $3291.7 \quad 2438.3$ & 25.9 \\
\hline
\end{tabular}

Table 9. Summary of cost of expenditure for the two irrigation system for (0.036ha) area of land.

\begin{tabular}{lll}
\hline \multirow{2}{*}{ Description } & \multicolumn{2}{l}{ Cost in Birr for two irrigation system } \\
\cline { 2 - 3 } & drip & furrow \\
\hline Labour expense & 2520 & 2520 \\
Material expense & 4159.68 & - \\
Agricultural inputexpense & 646.55 & 646.55 \\
Fuel & 696 & 696 \\
Grand Total & $\underline{8022.23}$ & $\underline{3862.55}$ \\
\hline
\end{tabular}

\subsection{Yield and Yield Related Parameters of Tomato Varieties UnderDrip Irrigation Method}

Analysis of Variance (ANOVA) showed significant difference for yield characters among the tomato varieties. Significant differences in tomato single fruit weight (g) were observed among varieties under drip irrigation system at $(p \leq 0.05)$ (Table 1) that ranged from 61.35 (for Melkashola) to $100.75 \mathrm{~g}$ (for Fetan). This is in agreement with the finding of [13] who reported a wide range of difference (6.18 -74.91 g) of tomato fruit weight. But, no significant variations among the varieties for fruit width and length were observed. Significantly higher yield (45.07 ton $\mathrm{ha}^{-1}$ ) was seen under Cochorowhile the lower (43.07 ton $\mathrm{ha}^{-1}$ ) was seen under Melkashola (Table 1). Similarly, [15] reported that the yields of these varities are between the ranges of30.0 to 45.0 ton $\mathrm{ha}^{-1}$.

\subsection{Growth Traits for Tomato Varieties UnderDrip Irrigation Method}

Comparing the plant height under drip irrigation system for selected tomato varieties, a wide range of difference was observed (46.3 to $58.2 \mathrm{~cm})$. Similarly, [12], [11] reported a wide range of differences in plant height of these tomato varieties; i.e., 40.2 to $107 \mathrm{~cm}$ and from 57.74-68.04 cm respectively. Melkashola is the tallest $(60.2 \mathrm{~cm})$ while fetan is the shortest $(47.05 \mathrm{~cm})$. Cochoro and Chaliwere found in between the two. Significance differences for number of branch were also seenbetween some varieties. It ranged in between 5.02and 8.12 with highest number for Fetan and lower for Cochoro (Table 2). This is in agreement with 11] who reported a wide range of differencesfor number of branches per plant for these tomato varieties (4.72 to 9.3).

Significant difference for the most yields indicating which are number of fruit and number of cluster per plant were seen among Fetan and the othersvarities. Number of fruits per plant ranges in between 18.22 to 35.57. Many authors such as [11], [4], found number of fruits per plant of tomato varieties in the range of 8.10-36.12 and 4-97 respectively. Lower number of fruit per plant (18.22) cluster per plant (6.12) was recorded under Fetan variety, while the others are gave more or less similar values of number of fruit andand number of cluster respectively (Table 2). But when we compare the yield between Fetan, Melkashola and Chali significantly 
higher yield was seen under Fetan than the other two. That may be due to higher single fruit weight recorded under fetan than the other (Table 1and 2). Thus, in our study, Fetan and Cochoro perform significantly higher yield than both Chali and Melkashola under drip irrigation system.

\subsection{Yield and Other Parameters of Tomato Varieties UnderFurrow Irrigation Method}

Results of the analysis of variance revealed significant difference for some of the characters among the tomato varieties. Significant variation in tomato single fruit weight (g) was observed between Chali and other varieties under furrow irrigation system at $(p \leq 0.05)$. Like that of drip irrigation, significantly lower tomato single fruit weight $(60$ g) was observed under Melkashola while the highest one was recorded under Fetan (88.5 g). This is in agreement with the finding of [19], who reported a wide range of difference (40.4 -86.4 g). Comparing the yield which is the most important parameter, significantly different yield was seen among some varieties. Similar to drip system Cochoro perform well than other (Table3).

\subsection{Growth Traits for Tomato Varieties Under Furrow Irrigation Method}

A wide range of difference was observed for plant height (59.37 to $95.12 \mathrm{~cm}$ ) among tested varities which is in agreement with reports of other authors such as [12] (40.2 to $107 \mathrm{~cm})$, [11] (57.74-68.04 cm) and [4] (4-97 cm). Similar to drip system highest plant height was seen under Melkashola than others. Melkashola is the tallest $(95.5 \mathrm{~cm})$ while Fetan is the shortest $(59.5 \mathrm{~cm})$ (Table 4). Even though no significant differences for number of branch and numbers of fruit per plant of tomato varieties were observed, number of branch vary between 6.02 and 7.87 while number of fruit per plant vary between 21 and 34.5 respectively (Table 4). [11] reported that number of branch ranges between 4.72 and 9.3 while, number of fruit per plant ranges between 8.10 and 36.12 respectively. This is similar with that of drip irrigation system in study area. A wide range of difference was observed for number of cluster per plant (5.91 to 15.05) which is in line with finding of [17].

\subsection{Comparison of Yield and Yield Related Parameters of Tomato Under Two Irrigation System}

There was observed difference in parameters of tomato under the two irrigation system. Mean single fruit weight and fruit width were significantly affected by the two irrigation system. Higher fruit weight and fruit width were seen under drip than furrow irrigation system, but fruit length was not significantly differed (Table 5). Yield which is the most important parameters is significantly affected under the two irrigation system. Relatively higher mean yield of tomato (44.09 ton $\mathrm{ha}^{-1}$ ) was recorded under drip irrigation than furrow one (43.38 ton $\mathrm{ha}^{-1}$ ) (Table 5). In line with results of this study, [19], [17] reported that yieldof tomato under drip system was found higher by $44 \%$ and $47 \%$ respectively as compared to the surface irrigation method. So considering the yield, as the most parameters for comparison between the two systems, all tomato varieties were showed better yield under drip than furrow irrigation system (Table 1 and 3). Other vegetative traits such as plant height and number of cluster per plant also showed significant difference between the two irrigation system; where higher plant height and number of cluster per plant were recorded in furrow irrigation system. Though it was no significant difference between the two irrigation systems, other vegetative traits like number of fruit per plant and number of branches per plant have also showed better results under furrow irrigation system. This might be due to more water consumption and more wetting pattern under furrow irrigation than drip irrigation system. So from present study the main factor for yield difference between the two irrigation system is the fruit size which determined by single fruit weight and width. It was Cochoro variety which performs well under both systems with mean average yield of 44.92 ton $\mathrm{ha}^{-1}$.

Pearson correlation coefficient of yield showed that it had a positive correlation with all characters except for fruit length and plant height (Table 7). This is in agreement with the finding of [15]. Number of fruit per plant showed negative correlation with single fruit weight. This might be due to the variety which have highest number of fruits per cluster had relatively small size of fruit. Positive association of plant height, number of fruit per plant and number of cluster per plant was found. Similar results are also reported by [15]. In generally, association of characters indicated that fruit yield per plant, number of fruits per plant, number of fruit cluster per plant are the most important parameters whichcontributes more forhigheryield per hectare for most varieties except for Fetan which was mainly governed by single fruit weight.

\subsection{Estimation of Installation Cost and Water Use Efficiency of Low Cost Drip Irrigation}

Results of the study revealed that approximately 87.78 and $118.5 \mathrm{~m}^{3}$ of irrigation water was applied to tomato using drip and surface irrigation systems respectively, during the entire crop growing period. The meantomato yield was recorded as 44.09 and 43.38 ton $\mathrm{ha}^{-1}$, respectively, for drip and surface irrigation methods. Drip irrigation showed a saving of $25.9 \%$ water and $1.6 \%$ higher yield as compared to surface irrigation (Table 8). Water saving of drip system was also reported by [17], which is up to $39 \%$ as compared to the surface system. Similarly [18] reported that $44 \%$ yield increment and $79 \%$ water saving under drip irrigation in tomato production than furrow irrigation system. In our study, water use efficiency was recorded to be 22.1 and $13.5 \mathrm{kgm}^{-3}$ for drip and surface method, respectively. Similarly, [17] found that the drip system almost double the water productivity value by $13.1 \mathrm{~kg} \mathrm{~m}^{-3}$ for tomato production.

An investment of 4159.68 birr was estimated for installation of a drip system for 0.036 ha of tomato 
cultivation. A grand total of about 8022.23 birr was spent for different items during tomato production season (Table 9). On the other hand, converting the yield obtained underlow cost drip irrigation system in to birr which was about 19400 birr, there is a promising result. An estimate of about 7900 birr was gained during the first year.

\section{Conclusion and Recommendation}

The study indicated that low cost drip irrigation system had showed better performance on tomato yield and other yield related parameters as compared to conventional furrow irrigation system. Less amount of irrigation water demand under drip irrigation were seen. Drip irrigation used less water than used by the surface irrigation systems thus giving much higher water use efficiencies. Low cost drip systems achieved water saving of more than $25.9 \%$ when compared to surface irrigation systems. It can be concluded from the present study that using low cost drip irrigation for tomato production is a profitable and best alternative. Finally, this technology needs further evaluation under farmer circumstance for better finding before widely disseminating to users.

\section{Acknowledgment}

The authors would like to thank Oromia Agricultural Research Institute for funding the research and Adami Tulu Agricultural Research Center for providing all the necessary facilities required for the research. We want to thank also Melkasa Agricultural Research Center (MARC) for providing us planting materials (seed) of tomato varieties.

\section{References}

[1] Ali, M. H., M. R. Hoque, A. A. Hassan, and A. Khair. 2007. Effects of deficit irrigation on yield, water productivity and economic returns of wheat. Agricultural Water Management 92:151-161.

[2] Baye, B., 2011. Effect of mulching and amount of water on the yield of tomato under drip irrigation. Journal of Horticulture and Forestry 3 (7), pp. 200-206.

[3] Chandra A. M. and J. Morrison, 2013. Advances and Challenges with Micro-Irrigation. Irrig. and Drain. 62: 255261.

[4] Chernet, S., D. Belew and F. Abay, 2013. Genetic variability and association of characters in tomato (Solanumlcopersicon L.) genotypes in Northern Ethiopia. Int. J. Agric. Res., 8: 6776.

[5] Desalegne, L., 2002. Tomatoes: Researchexperience and production prospects. Research reports No43, Ethiopian Agricultural Research Organization, Addis Ababa, Ethiopia, pp: $1-15$.

[6] Fekadu Y, Teshome T. 1998. Effect of drip and furrow irrigation and plant spacing on yield of tomato at Dire Dawa, Ethiopia. Agricultural Water Management 35: 201-207.
[7] FassilEshetu, KassaTadele and SelemonNega, 2004. Micro Tube Drip Irrigation. A Report.

[8] FAO, 1997. Small-scale irrigation for arid zones: Principles and options.

[9] Gawad, G. A., Arslan, A., Gaihbe, A., and Kadouri, F., 2005. The effects of saline irrigation water management and salt tolerant tomato varieties on sustainable production of tomato in Syria. Agricultural Water Management 78: 39-53.

[10] Isaya V. Sijali, 2001. Drip Irrigation. Options for smallholder farmers in eastern and southern Africa. Published by Sida's Regional and Land Management Unit.

[11] Jiregna, T. D., 2013. "Evaluation of agronomic performance and Lycopene variation in tomato (Lycopersicomesculentum Mill.) genotypes in Mizan, Southern Ethiopia." World Applied Sciences Journal, 27 (11), 1450-1454.

[12] Meseret, D. R., Ali, M. and Kassahun, B, 2012. "Evaluation of tomato (Lycopersiconesculentum Mill.) genotypesfor yield and yield components," Journal of Plant Science and Biotechnology, Global science books.

[13] Muhammad, Y. S., Muhammed, A. and Qumer, I., 2013. "Augmented analysis for yield and some yield components in tomato (Lycopersicomesculentum Mill.)," Pak. J. Bot., 45 (1), 215-218.

[14] Pawar DD, Bhoi PG, Shinde SH. 2002. Effect of irrigation methods and fertilizer levels on yield of potato. Indian Journal of Agricultural Sciences 72 (2): 80-83.

[15] Ragassa, M. D., A. Mohammed and K. Bantte, 2012. Evaluation of tomato (Lycopersicomesclentum mill.) genotypes for yield and yield components. Afr. J. plant Sci. Biotechnol., 6:45-49.

[16] Raina JN, Thakur BC, Bhandaria R, 1998. Effect of drip irrigation and plastic mulch on yield, water use efficiency and benefit-cost ratio of pea cultivation. Indian J. Soil Sci.

[17] Satyendra K., Rajbir S., M. J. Kaledhonkar, D. D. Nangare and Ashwani K., 2013. Improving Water Productivity Through Micro-Irrigation In Arid Punjab Regions. Irrig. and Drain. 62: 330-339.

[18] Shah S. K., 2011. Towards Adopting Nanotechnology in Irrigation: Micro Irrigation Systems. India Water Portal: Karnataka, India.

[19] Shushay C., Derbew B. and Fetien A, "Performance Evaluation and Path Analysis Studies in Tomato (Solanumlycopersiconl.) Genotpes under Humera, Northern Ethiopia Condition." World Journal of Agricultural Research, vol. 2, no. 6 (2014): 267-271. doi: 10.12691/wjar-2-6-3.

[20] Teshome Abdissa, Nigusse Dechassa and Yibekal Alemayehu, 2012. Sweet potato growth parameter as affected by farm manure and phosphorus application at Adami Tulu agricultural research center central rift valley of Ethiopia. Agricultural science journal 2 (1):1-12.

[21] Zaman WU, Arshad M, Saleem K, 2001. Distribution of nitrate nitrogen in the soil profile under different irrigation methods. International, J. Agri. Biol., 2: 208-9. 